\title{
Zinc and genital infections
}

\author{
M S CORNELL,${ }^{*}$ L J HINKS, ${ }^{*}$ H S K SINGHA,$\dagger$ V WALKER, ${ }^{*}$ F E WILLMOTT $\dagger$ \\ From the *Department of Chemical Pathology and Human Metabolism, University of Southampton Medical \\ School, and the †Department of Genitourinary Medicine, Royal South Hants Hospital, Southampton
}

SUMMARY The zinc status of 19 patients with chronic or recurrent genital infections and 18 patients with non-recurrent genital infections was assessed by measuring plasma and leucocyte zinc concentrations. Neither group of patients had plasma or leucocyte zinc concentrations that differed significantly from those of matched healthy controls. Each of six patients with chronic candidiasis had anergy to candidal antigen, as shown by delayed cutaneous hypersensitivity to intradermal injection of the antigen, but their zinc status was normal. This study provided no evidence of zinc deficiency in this small number of patients with acute non-recurrent or chronic recurrent genital infections.

Certain genital infections are notable for their ability to recur or become chronic, giving rise to considerable suffering and distress. Factors responsible for chronicity have not been fully elucidated, but evidence is increasing that abnormalities in immune responses may be important. ${ }^{1-3}$ The trace element zinc has a role in cell mediated immunity, and zinc deficiency is associated with depression of cell mediated immunity. ${ }^{4}$ Preliminary reports have suggested that zinc treatment may be beneficial in chronic trichomoniasis ${ }^{5}$ and herpes genitalis. ${ }^{67}$ Recent work indicates that concentrations of zinc in circulating leucocytes reflect tissue zinc concentrations closely and more reliably than plasma zinc concentrations. ${ }^{89}$ This study was undertaken to find out, from measurements of plasma and leucocyte zinc concentrations, whether patients with recurrent genital infections are zinc deficient.

\section{Patients and methods}

Patients attending the department of genitourinary medicine of the Royal South Hants Hospital, Southampton, were studied with their informed consent. Approval of the District Joint Ethical Committee was obtained. Group A comprised 19 patients, five men and 14 women, aged 20 to 52 (mean 30.6) years with

Address for reprints: Mr M S Cornell, c/o Chemical Pathology and Human Metabolism, Level D, South Laboratory and Pathology Block, Southampton General Hospital, Tremona Road, Southampton SO9 4XY.

Accepted for publication 22 November 1986 chronic or recurrent genital infection of at least 12 months duration (with at least three episodes in the previous year), which failed to respond to conventional treatment. Group B comprised 18 patients, five men and 13 women, aged 19 to 45 (mean 26.2) years who were experiencing a single episode of nonrecurrent genital infection, which responded to conventional treatment. No patient was receiving, or had recently received, zinc supplements. Normal plasma and leucocyte zinc concentrations were obtained from previous work carried out in this department. ${ }^{10}$ The clinical details for both groups are listed in table 1.

Patients in group A answered a questionnaire to assess factors that might influence their zinc status and to look for evidence of zinc deficiency. Their nutritional status was assessed from measurements of height, weight, mid-arm circumference, and triceps skinfold thickness. Routine specimens were taken for identification of Neisseria gonorrhoeae, Chlamydia trichomatis, Candida albicans, and Trichomonas vaginalis. Blood was taken for syphilis serology tests, full blood counts, and estimation of random blood sugar, plasma zinc, and leucocyte zinc concentrations. Women with recurrent candidal infection had delayed cutaneous hypersensitivity to Candida spp assessed by injecting $0.02 \mathrm{ml}$ candidal antigen (Bencard) intradermally and reading the result at 15 minutes and $\mathbf{4 8}$ hours.

Plasma zinc concentration was measured using a modified version of the method of Meret and Henkin. ${ }^{11}$ Between batch precision was $3 \cdot 1 \%$. Leucocytes were separated and analysed for zinc content as described previously. ${ }^{12}$ This assay had a between batch precision of $3 \cdot 8 \%$. 
Table 1 Infections in 37 patients studied

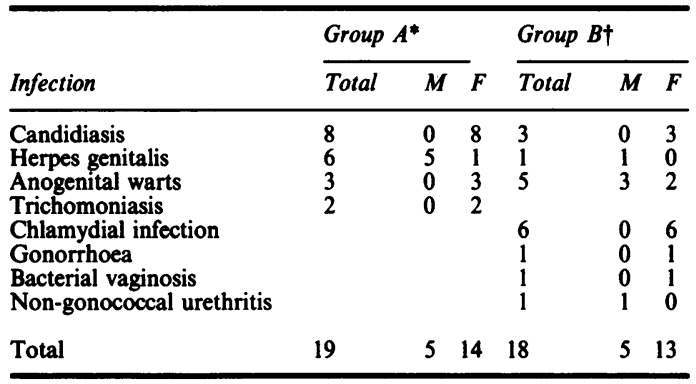

* Patients with chronic or recurrent infection.

†Patients with non-recurrent infection.

\section{Results}

From anthropometric measurements, 14 of the patients in group $\mathbf{A}$ had normal nutritional status as assessed by the body mass index ${ }^{13}$ and triceps skinfold thickness. ${ }^{14}$ Two patients were marginally, and two moderately, underweight, and one was obese. From the questionnaire no patient was identified as having features of zinc deficiency. In six patients factors were identified that might have predisposed to zinc deficiency, but their zinc status was normal.

Neither group A nor group B patients had plasma or leucocyte zinc concentrations that differed significantly from those of their matched healthy controls ( $p>0.05$, Mann Whitney test, table 2), and there was no difference between the two patient groups $(p>0.05)$. In the 19 patients with chronic infections (group A), no subgroup was identified with consistently low zinc concentrations (table 3 ).

Six of the eight patients with chronic candidal infection were tested for their response to candidal antigen. All six were found to be anergic to the antigen.

\section{Discussion}

Willmott et al reported on a patient with recalcitrant trichomoniasis that responded to oral zinc therapy. ${ }^{5}$ She had a marginally low plasma zinc concentration that rose with treatment to within the normal range. The plasma zinc concentration may be lowered in response to a number of factors, however, including stress, and a low plasma zinc concentration may not indicate zinc deficiency. For this reason the zinc concentration was also measured in circulating leucocytes in this study, as a better reflection of tissue zinc concentrations. $^{89}$

Zinc deficiency is associated with depressed cell mediated immunity and increased susceptibility to infections, particularly with $C$ albicans. ${ }^{15}$ Some patients with chronic genital candidiasis have a specific defect in their immune response. In one study by Meech et al, ${ }^{16} 23 \%$ of 22 patients were anergic to candidal antigen and $50 \%$ were hypersensitive. Their zinc status was not investigated. Some patients with chronic genital candidiasis possibly have subclinical zinc deficiency. In this study there was evidence of decreased cell mediated immunity in all six patients with chronic candidiasis who were tested. None of

Table 2 Plasma and leucocyte zinc concentrations

\begin{tabular}{|c|c|c|c|c|c|c|}
\hline \multirow[b]{2}{*}{ Subjects } & \multicolumn{3}{|c|}{ Plasma zinc ( $\mu \mathrm{mol} / \mathrm{l})$} & \multicolumn{3}{|c|}{ Leucocyte zinc (pmol/10 $10^{6}$ cells) } \\
\hline & Number & Median & Observed range & Number & Median & Observed range \\
\hline \multicolumn{7}{|l|}{ Women: } \\
\hline $\begin{array}{l}\text { Group A* } \\
\text { Matched controls } \\
\text { Group B† } \\
\text { Matched controls }\end{array}$ & $\begin{array}{l}13 \\
26 \\
13 \\
26\end{array}$ & $\begin{array}{l}13 \cdot 5 \\
12 \cdot 8 \\
14 \cdot 1 \\
12 \cdot 6\end{array}$ & $\begin{array}{r}12 \cdot 0-17 \cdot 3 \\
10 \cdot 0-16 \cdot 4 \\
10 \cdot 6-19 \cdot 8 \\
8 \cdot 7-16 \cdot 1\end{array}$ & $\begin{array}{l}14 \\
28 \\
13 \\
26\end{array}$ & $\begin{array}{r}98 \\
112 \\
92 \\
98\end{array}$ & $\begin{array}{l}83-136 \\
79-156 \\
78-146 \\
79-142\end{array}$ \\
\hline \multicolumn{7}{|l|}{ Men: } \\
\hline $\begin{array}{l}\text { Group } A^{*} \\
\text { Matched controls } \\
\text { Group B } † \\
\text { Matched controls }\end{array}$ & $\begin{array}{r}5 \\
10 \\
4 \\
8\end{array}$ & $\begin{array}{l}15 \cdot 4 \\
13 \cdot 4 \\
14 \cdot 0 \\
13 \cdot 0\end{array}$ & $\begin{array}{l}12 \cdot 2-16 \cdot 4 \\
10 \cdot 4-16 \cdot 5 \\
13 \cdot 4-16 \cdot 3 \\
11 \cdot 5-16 \cdot 7\end{array}$ & $\begin{array}{r}5 \\
10 \\
5 \\
10\end{array}$ & $\begin{array}{r}98 \\
112 \\
107 \\
106\end{array}$ & $\begin{array}{l}86-105 \\
83-135 \\
85-139 \\
90-153\end{array}$ \\
\hline
\end{tabular}

*Patients with chronic or recurrent infection.

+Patients with single episode of non-recurrent infection.

Table 3 Plasma and leucocyte zinc concentrations in patients (men and women) with chronic infections

\begin{tabular}{|c|c|c|c|c|c|}
\hline \multirow[b]{2}{*}{ Infection } & \multirow[b]{2}{*}{ Number } & \multicolumn{2}{|c|}{ Plasma zinc ( $\mu$ mol/l) } & \multicolumn{2}{|c|}{ Leucocyte zinc (pmol/106 cells) } \\
\hline & & Median & Range & Median & Range \\
\hline $\begin{array}{l}\text { Candidiasis } \\
\text { Herpes genitalis } \\
\text { Anogenital warts } \\
\text { Trichomoniasis }\end{array}$ & $\begin{array}{l}8 \\
6 \\
3 \\
2\end{array}$ & $\begin{array}{l}13 \cdot 6 \\
14 \cdot 8 \\
12 \cdot 3 \\
14 \cdot 8\end{array}$ & $\begin{array}{l}12 \cdot 1-16 \cdot 0 \\
12 \cdot 2-16 \cdot 4 \\
12 \cdot 0-12 \cdot 5 \\
12 \cdot 2-17 \cdot 3\end{array}$ & $\begin{array}{r}92 \\
95 \\
101 \\
109\end{array}$ & $\begin{array}{r}84-136 \\
86-105 \\
100-129 \\
83-136\end{array}$ \\
\hline
\end{tabular}


these patients had biochemical evidence of zinc deficiency, however, and alternative explanations must be sought for the altered immune response in genital candidiasis.

Studies have claimed that zinc treatment may be effective against herpes genitalis. ${ }^{67}$ The observed responses might have been caused by the direct action of zinc on the infecting agent ${ }^{17}$ or to the correction of a subclinical zinc deficiency state. The study published here found a normal zinc status in each of six patients with recurrent herpes genitalis.

In conclusion, the results of this investigation on a small number of patients showed no evidence of zinc deficiency in patients with either acute or chronic and recurrent genital infections.

We thank the staff of the department of genitourinary medicine for all their help and support.

\section{References}

1 Hobbs JR, Brigden D, Davidson F, Kahan M, Oates JK. Immunological aspects of candidal vaginitis. Proceedings of the Royal Society of Medicine 1977;70 suppl 4:11-3.

2 Donnenberg $\mathrm{AD}$, Chaik of $\mathrm{E}$, Aurelian $\mathrm{L}$. Immunity to herpes simplex virus type 2: cell mediated immunity in latently infected guinea pigs. Infect Immun 1980;30:99-109.

3 Barnett N, Mak H, Winkelstein JA. Extensive verrucosis in primary immunodeficiency diseases. Arch Dermatol 1983; 119:5-10.

4 Prasad AS. Clinical, biochemical and pharmacological role of zinc. Annu Rev Pharmacol Toxicol 1979;20:393-426.

5 Willmott FE, Say J, Downey D, Hookham A. Zinc and recalcitrant trichomoniasis. Lancet 1983;i:1053.

6 Jones R. Genital herpes and zinc. Med J Aust 1979;1:286.

7 Fahim MS, Browner TA. Treatment of genital herpes simplex virus in male patients. Arch Androl 1980;4:79-85.

8 Meadows NJ, Ruse W, Smith MF, et al. Zinc and small babies. Lancet 1981;ii:1135-6.

9 Delves HT. Assessment of trace element status. Clin Endocrinol Metab 1985;14:725-59.

10 Hinks LJ, Clayton BE, Lloyd RS. Zinc and copper concentrations in leucocytes and erythrocytes in healthy adults and the effect of oral contraceptives. J Clin Pathol 1983;36:1016-21.

11 Meret S, Henkin RI. Simultaneous determination of $\mathrm{Cu}$ and $\mathrm{Zn}$ in serum, urine and cerebrospinal fluid. Clin Chem 1971;17: 369-76.

12 Hinks LJ, Colmsee M, Delves HT. Determination of zinc and copper in isolated leucocytes. Analyst 1982;107:815-823.

$13 \mathrm{Knight} I$. The heights and weights of adults in Great Britain. London: Her Majesty's Stationery Office, 1984:84.

14 Truswell AS. ABC of nutrition: measuring nutrition. $\mathrm{Br}$ Med J 1985;291:1258-62.

15 Aggett PJ, Harries JT. Current status of zinc in health and disease states. Arch Dis Child 1979;54:909-17.

16 Meech RJ, Smith JM, Chew T. Pathogenic mechanisms in recurrent genital candidosis in women. NZ Med J 1985;98:1-5.

17 Gordon YJ, Asher Y, Becker Y. Irreversible inhibition of herpes simplex virus replication in BSC-1 cells by zinc ions. Antimicrob Agents Chemother 1975;8:377-80. 